\title{
PERBEDAAN HASIL BELAJAR EXAMPLE NON EXAMPLE TERHADAP SISWA KELAS 5 PADA MATA PELAJARAN IPA
}

\author{
Ina Lestari ${ }^{1}$, Indri Anugraheni ${ }^{2}$
}

Prodi Pendidikan Guru Sekolah Dasar, Fakultas Keguruan dan Ilmu Pendidikan Universitas Kristen Satya Wacana, Indonesia

\section{Info Artikel}

Sejarah Artikel:

Diterima Februari 2017

Disetujui Mei 2017

Dipublikasikan Juni 2017

Keywords:

Differences in Learning

Outcomes Example Non

Example Against Students on Science Subjects

\begin{abstract}
The problem in this research is "Differences of Cooperative Learning Outcomes Type Example Non Example Media Assisted Images Against 5th Grade Students of State Elementary School Bener 02 In Science Subject Semester II, with sub research problem that is, student learning outcomes control group on science subjects in Process materials Soil Formation due to weathering in 5th grade State Elementary School Bener 01, student learning outcomes experimental group on science subjects in the process of Soil Formation process due to weathering in 5th grade State Elementary School Bener 02 and Differences of control group learning outcomes with experimental group applying the model of learning Example Non Example media-aided images on science subjects in materials The process of Soil Formation due to weathering in 5th grade State Elementary School Bener. Variables in this study consisted of independent variables and dependent variables, this study using experimental methods, with the form of research is a quasi-experimental research. The experimental design used in this research is Pretest Posttest Control Group Design. Population in this research that is all student of class 5 which amounted to 63 student. This sampling technique using saturated sample technique. Data collection techniques used in this research are test, observation and documentation. Based on the analysis of data obtained: the average of control group learning outcomes amounted to 69,336, student learning outcomes in the experimental group amounted to 84.454, based on the calculation using $t$ test in obtaining the value of significance / probability $0.000<0.05$ then $H_{-} 0$ rejected then $\mathrm{Ha}$ accepted. This means that there are differences in the results of science learning significance in grade 5 students of State Elementary School Bener 02 in learning using the model of learning Example Non Example.
\end{abstract}

\begin{abstract}
Abstrak
Masalah dalam penelitian ini adalah "Perbedaan Hasil Belajar Kooperatif Tipe Example Non Example Berbantuan Media Gambar Terhadap Siswa Kelas 5 SD Negeri Bener 02 Pada Mata Pelajaran IPA Semester II, dengan sub masalah penelitian yaitu, hasil belajar siswa kelompok kontrol pada mata pelajaran IPA dalam materi Proses Pembentukan Tanah Karena Pelapukan di kelas 5 SD Negeri Bener 01, hasil belajar siswa kelompok eksperimen pada mata pelajaran IPA dalam materi Proses pembentukan Tanah Karena Pelapukan di kelas 5 SD Negeri Bener 02 serta Perbedaan hasil belajar siswa kelompok kontrol dengan kelompok eksperimen yang menerapkan model pembelajaran Example Non Example berbantuan media gambar pada mata pelajaran IPA dalam materi Proses Pembentukan Tanah Karena Pelapukan di kelas 5 SD Negeri Bener. Variabel dalam penelitian ini terdiri dari variabel bebas dan variabel terikat, Penelitian ini menggunakan metode eksperimen, dengan bentuk penelitiannya adalah penelitian eksperimen semu. Desain eksperimen yang digunakan dalam penelitian ini adalah Pretest Posttest Control Group Design. Populasi dalam penelitian ini yakni seluruh siswa kelas 5 yang berjumlah 63 siswa. Teknik pengambilan sampel ini menggunakan teknik sample jenuh. Teknik pengumpulan data yang digunakan dalam penelitan ini adalah tes, observasi dan dokumentasi. Berdasarkan analisis data pembahasan diperoleh : rata-rata hasil belajar kelompok kontrol sebesar 69.336, hasil belajar siswa pada kelompok eksperimen sebesar 84.454, berdasarkan hasil perhitungan menggunakan uji $\mathrm{t}$ di peroleh nilai signifikansi/probabilitas $0,000<0,05$ maka Ho ditolak maka Ha diterima. Artinya terdapat perbedaan hasil belajar IPA yang signifikansi pada siswa kelas 5 SD Negeri Bener 02 dalam pembelajaran menggunakan model pembelajaran Example Non Example.
\end{abstract}

(C) 2017 Universitas Muria Kudus

Kampus UMK Gondangmanis, Bae Kudus Gd. L. 1t I PO. BOX 53

Kudus

Tlp (0291) 438229 ex.147 Fax. (0291) 437198

E-mail: ina02lestari@gmail.com 


\section{PENDAHULUAN}

Undang-undang No. 20 Tahun 2003 pasal 1, pendidikan adalah suatu usaha mewujutkan belajar dan proses pembelajaran, agar siswa aktif dalam mengembangkan potensi dirinya untuk memiliki pengendalian diri, kecerdasan, kepribadian ahlak mulia, kekuatan spiritual keagamaan, serta ketrampilan dirinya dalam masarakat, bangsa dan negara. Untuk mencapai tujuan tersebut guru harus mampu menciptakan lingkungan belajar, supaya dapat mendorong siswa untuk mengembangkan potensi dirinya masing-masing.

Salah satu upaya meningkatkan mutu pendidikan di sekolah adalah dengan cara melalui perbaikan proses belajar mengajar. Berbagai konsep dan wawasan baru tentang proses belajar mengajar di sekolah telah muncul dan berkembang sesuai pesatnya perkembangan ilmu pengetahuan teknologi. Guru sebagai personil yang menduduki posisi strategis dalam rangka pengembangan sumber daya manusia, dituntut untuk terus mengikuti perkembangan konsep-konsep baru dalam dunia pendidikan tersebut.

Upaya peningkatan kualitas sumber daya manusia terutama mutu pendidikan di Sekolah Dasar merupakan tugas utama. Mengingat betapa pentingnya pendidikan bagi kehidupan, maka pendidikan harus dilaksanakan sebaik-baiknya sehingga proses hasil yang maksimal. Salah satu mata pelajaran di Sekolah dasar yang masuk dalam UN adalah Ilmu Pengetahuan Alam (IPA).

Mengingat pentingnya pembelajaran IPA, maka semua siswa hendaknya dapat menguasai pelajaran IPA dengan baik. Sebagai seorang guru harus bisa menguasai kemampuan, keterampilan dalam menyajikan materi pelajaran IPA dan membutuhkan ide-ide kreatif dalam penyampaian materi kepada siswa sehingga dapat mengembangkan siswa secara menyeluruh dan utuh karena dalam kegiatan IPA melibatkan semua aspek yaitu: emosional, intelektual dan psikomotor sehinga dapat mencapai kemampuan peserta didik yang meliputi: kognitif, afektif, dan psikomotor.

Berdasarkan observasi siswa kelas 5 SD Negeri Bener 02 Kecamatan Tengaran Kabupaten Semarang. Siswa kurang antusias dalam mengikuti pembelajaran IPA dan menurunnya hasil belajar pada mata pelajaran IPA. Hanya beberapa siswa yang aktif dalam proses pembelajaran, sisanya pasif dan kurang memperhatikan dalam mengikuti pembelajran. Oleh karena itu perlu diadakan perbaikan pembelajaran IPA agar dapat memperbaiki, meningkatkan hasil belajar IPA yang lebih maksimal dan dapat mencapai rata-rata di atas KKM yaitu 70 .

Perbaikan pembelajaran dapat dilakukan guru dengan cara memilih dan menetapkan model pembelajaran yang tepat untuk menyampaikan materi pembelajaran di kelas, salah satunya adalah melalui pemilihan model pembelajaran kooperatif Example Non Example Berbantuan Media Gambar.

Berdasarkan uraian di atas, penulis ingin mengetahui lebih lanjut mengenai "Perbedaan Hasil Belajar Kooperatif Tipe Example Non Example Berbantuan Media Gambar Terhadap Siswa Kelas 5 SD Negeri Bener 02 Kecamatan Tengaran Kabupaten Semarang Pada Mata Pelajaran IPA Semester II.

\section{METODE}

Metode yang dianggap tepat digunakan dalam penelitian ini adalah metode eksperimen semu. Pada eksperimen semu ini rumusan masalah harus mengandung hubungan sebab akibat antara variabel yang sudah ditemukan pada saat merumuskan latar belakang. Menurut Sugiyono (2010:107) penelitian eksperimen adalah penelitian yang digunakan untuk mencari pengaruh perlakuan tertentu terhadap yang lain dalam kondisi yang terkendalikan.

Rancangan penelitian yang digunakan dalam penelitian ini adalah desain Pretest Posttest Control Group Desig Penelitian ini terdapat dua variabel, yaitu variabel bebas (X) dan variabel terikat (Y). Variabel bebas merupakan tindakan yang mempunyai pengaruh terhadap variabel terikat. Variabel terikat adalah hasil dari penyelesaian soal IPA.

Populasi dalam penelitian ini adalah kelas 5 di SD Negeri Bener yang berjumlah 63 siswa. Dengan karakteristik populasi merupakan siswa kelas 5 SD Negeri Bener 01 dan 02 tahun ajaran 2016/2017. Sedangkan kelas 5 SD Negeri Bener 01 Sebagai kelompok kontrol yang berjumlah 30 siswa dan kelas 5 SD Negeri Bener 02 sebagai kelompok eksperimen yang berjumlah 33 siswa.

Teknik pengumpulan data pada penelitian ini dilakukan dengan observasi, tes dan dokumentasi. Teknik analisis data terdiri atas Uji Prasyarat dan Uji Hipotesis. Uji Prasyarat terdiri atas uji normalitas dan uji homogenitas. Setelah dilakukan uji asumsi/uji prasyarat kemudian pengujian hipotesis yaitu dengan melakukan uji perbedaan pada hasil belajar menggunakan uji analisis deskriptif, yaitu menggunakan uji $\mathrm{t}$ melalui Independent Sample T-Test. 


\section{HASIL DAN PEMBAHASAN}

Penelitian yang dilakukan pada SD Negeri Bene, pada kelompok kontrol kegiatan pembelajaran yang tidak menerapkan model pembelajaran Example Non Example Berbantuan Media Gambar dimana guru hanya menggunakan model ceramah dalam proses pembelajarannya cenderung berlangsung monoton sehingga siswa kurang aktif namun cenderung pasif. Siswa cenderung ramai terkadang juga mendengarkan penjelasan dari guru. Berbeda dengan kelompok eksperimen yang menerapkan model pembelajaran Example Non Example Berbantuan Media Gambar ini menempatkan siswa pada pada posisi sangat dominan dalam proses pembelajaran dan terjadinya kerjasama dalam kelompok sehingga semua siswa berusaha untuk memahami dan mengetahui setiap jawaban dari gambar atau masalah yang ditemukan dan bertanggung jawab atas anggota kelompoknya masingmasing, sehingga siswa terlibat secara tolat dan berperan aktif saat proses pembelajaran berlangsung.

Rangkuman hasil belajar antara kelompok kontrol dengan menggunakan model Konvensional sedangkan kelompok eksperimen yang menggunakan model pembelajaran Example Non Example Berbantuan Media Gambar, dapat dilihat pada tabel berikut:

Tabel 1. Hasil Uji T-Test Kelompok Example Non Example dan Kelompok Konvensional Group Statistics

\begin{tabular}{|l|l|l|l|}
\hline \multicolumn{1}{|c|}{ Model } & $\mathrm{N}$ & Mean & \multicolumn{1}{c|}{$\begin{array}{c}\text { Std. } \\
\text { Deviation }\end{array}$} \\
\hline $\begin{array}{l}\text { Example Non } \\
\text { Example }\end{array}$ & 33 & 84.454 & 14.095 \\
\hline Konvensional & 30 & 69.366 & 11.645 \\
\hline
\end{tabular}

Berdasarkan tabel Group Statics di atas nilai rata-rata (mean) menunjukkan bahwa hasil belajar siswa kelompok eksperimen dengan model Example Non Example sebesar 84,454 tergolong tinggi. Sedangkan kelompok kontrol yang menggunakan model pembelajaran Konvensional sebesar 69.366 tergolong sedang. Adapun rentang atau kriteria yang digunakan sebagai berikut: 40-52 tergolong sangat rendah, 53-65 tergolong rendah, 66-78 sedang, 79-91 tergolong tinggi, 92-100 tergolong sangat tinggi.

Untuk mengetahui soal tes kelompok kontrol dan kelompok eksperimen berdistribusi normal maka dilakukan uji normalitas dengan menggunakan perangkat SPSS 16.00 for windows. Taraf signifikansi/probabilitas < nilai $\alpha(0,05) H_{0}$ ditolak, jika sebaliknya maka $H_{0}$ diterima.

Hasil uji normalitas soal kelompok kelompok eksperimen dan kelompok kontrol, dimana nilai Asymp, Sifg, (2-tailed) uji Kolmogoroy-Smirnov $Z$ hasil pengukuran Posttest kelompok eksperimen 0,584. Sedangkan hasil pengukuran Posttest kelompok 0,107 . Karena signifikansi/probabilitas soal pada kelompok eksperimen dan kelompok kontrol >0,05 maka $H_{0}$ diterima artinya, dapat disimpulkan bahwa persebaran data hasil pengukuran Posttest kelompok eksperimen dan kelompok kontrol berasal dari populasi yang berdistribusi normal.

Penelitian ini bertujuan untuk mengetahui perbedaan hasil belajar yang signifikan dalam penerapan model pembelajaran Example Non Example pada mata pembelajaran IPA kelas 5 SD bener 02 .

Keampuhan model pembelajaran Example Non Example berbantuan media gambar dimungkinkan karena dilaksanakannya langkah-langkah Example Non Example. Adapun isi langkah-langkah utama yang dilakukan pada pembelajaran menggunakan model Example Non Example adalah 1) guru menayangkan gambar yang relevan sesuai materi, 2) Guru membagi siswa menjadi kelompok, 3) guru meminta siswa untuk mempresentasikan hasil diskusinya dan menempelkan gambar pada tempat yang sudah disediakan. Pemberian penghargaan sangat diperlukan dalam setiap pembelajaran, walau hanya sekedar ucapan terimakasih atau dengan tepuk tangan dari seluruh siswa.dalam hal ini , sportifitas siswa akan tumbuh dan nampak.

Dari hasil analisis data, menunjukkan hasil yang signifikan karena hal ini disebabkan bahwa dengan penggunaan model pembelajaran Example Non Example siswa lebih kritis dalam menganalisi gambar, siswa mengetahui aplikasi dari materi berupa contoh gambar, dan siswa diberi kesempatan untuk mengemukakan pendapanya. Proses pembelajaran tersebut ternyata berpengaruh terhadap hasil belajar siswa.

Selain dilihat dari probabilitas dan signifikasinya, dapat juga di lihat dari perbedaan rata-rata nilai hasil belajar dari kelompok eksperimen maupun kelompok kontrol. Dalam kegiatan pembelajaran dengan menggunakan model pembelajaran Examples Non Examples terlihat hasil belajar siswa kelompok eksperimen yang berjumlah 33 siswa lebih tinggi di banding dengan hasil belajar siswa kelompok kontrol yang berjumlah 30 siswa. Data yang di peroleh membuktikan 
bahwa rata-rata hasil belajar siswa kelompok eksperimen adalah 84.4545 sedangkan kelompok kontrol 69.3667. Pada siswa data independent samples $t$ test terlihat bahwa nilai $\mathrm{t}$ hitung positif, artinya rata-rata nilai hasil belajar kelas eksperimen lebih tinggi dari pada kelompok kontrol.

\section{SIMPULAN}

Rata-rata hasil belajar siswa kelas 5 SD Negeri Bener pada mata pelajaran IPA dalam materi Proses Pembentukan Tanah Karena Pelapukan, pada kelas 5 SD Negeri Bener 02 sebagai kelompok eksperimen yang menggunakan model Eample Non Example Berbantuan Media Gambar sebesar 84.454 sedangkan pada kelas 5 SD Negeri Bener 01 sebagai kelompok kontrol dengan menggunakan model Konvensional sebesar 69.366. berdasarkan hasil uji t dengan taraf signifikansi $\mathrm{F}$ adalah 0.111 lebih besar dari 0,05 $(>0,05)$, maka $H_{0}$ diterima, dan sebaiknya jika nilai siknifikansi kurang dari $0,05(<0,05) H_{\square}$ ditolak. Jika $H_{0}$ ditolak maka $H_{a}$ diterima, menandakan bahwa adanya perbedaan yang signifikani antara kedua model. Dapat diketahui bahwa hasil uji $\mathrm{t}$ pada penelitian ini mempunyai $0,000<0,005$, maka dapat disimpulkan bahwa adanya perbedaan hasil yang signifikan antara kelompok eksperimen dan kelompok kontrol.

\section{DAFTAR PUSTAKA}

Apriani, Atik dan David Indrianto. 2010. Implementasi model pembelajaran examples non examples, IKIP PGRI SUMEDANG;FKIP PGMI.

Arikunta, 2010. Prosedur Penelitian Suatu Pendekatan Praktik; Jakarta: Rineka Cipta

Hamdani, 2011. Media Pembelajaran; Yogyakarta: Pustaka Pelajar

Huda, Miftahul. 2015. Model-model Pengangajaran dan Pembelajaran. Yogyakarta: Pustaka Pelajar

Ibrahim, Muslim. 2000. Pembelajaran Kooperatif. Surabaya: University Press

Iriani dan Sahrudin 2010.Model-model Pembelajaran.Bandung; PT Remaja Rosdakarya

Priyanto, Dwi. 2010. Pemahaman Analisis Statistik Data dengan SPSS. Yogyakarta: Mediakom

Sugiyono. 2010. Metode Penelitian Pendidikan Pendekatan Kulaitatif Kuantitatif, dan $R \& D$. Bandung: Alfabeta, CV

Sugiyono. 2010. Statistika Untuk Penelitian. Bandung: Alfabeta , CV

Suwarno Agus, 2016. Implementation of Inquiri on Student Learning Outcomes in Integrated IPS Subject, 7 (2): 12-15 